\title{
From the Oldowan to the Acheulean at Olduvai Gorge, Tanzania- An introduction to the special issue
}

Ignacio de la Torre ${ }^{1^{*}}$, Lindsay McHenry ${ }^{2}$ and Jackson $\mathrm{Njau}^{3,4}$

${ }^{1}$ Institute of Archaeology, University College London, 31-34 Gordon Square, WC1H OPY London, United Kingdom

${ }^{2}$ Department of Geosciences, University of Wisconsin-Milwaukee, 3209 N. Maryland Ave., Milwaukee, WI 53211, USA

${ }^{3}$ Department of Earth and Atmospheric Sciences, Indiana University, 1001 E 10th Street, Bloomington, IN 47405, USA

${ }^{4}$ Stone Age Institute, 1392 W Dittemore Rd., Gosport, IN 47433, USA

* Corresponding author: I. de la Torre i.torre@ucl.ac.uk

Keywords: Early Stone Age; East Africa; Plio-Pleistocene; hominin subsistence; paleoecology; chronostratigraphy

\section{Introduction}

Even before setting foot at Olduvai Gorge, Louis Leakey was certain that he would find handaxes there (Leakey, 1951). Apparently, he did so on the very first day of the 1931 expedition, the first that Louis Leakey ever conducted at Olduvai. More unexpectedly, Louis Leakey also found an archaic, handaxefree industry in the lower beds of Olduvai (Leakey et al., 1931), which then he formally termed Oldowan (Leakey, 1936). In one way or another, all studies on the transition from the Oldowan to the Acheulean in East Africa and elsewhere, stem from Louis Leakey's (e.g., 1936, 1951) initial reports at Olduvai, the first site where a stratigraphic sequence showed that handaxes emerged after a coreand-flake technology.

Such studies are many, among which Mary Leakey's (1971) 'Olduvai Gorge. Volume 3' stands out as the pivotal work that shaped the empirical, methodological and conceptual frameworks of the Oldowan-Acheulean transition. Leakey (1971) reported on excavations that were methodologically exemplary, and produced painstaking descriptions of lithic assemblages to characterise the Oldowan, the Acheulean and the transitional industries between the two cultures (i.e., Developed Oldowan A and B), within well-constrained geological contexts. The superb quality of Leakey's (1971) analysis and publication, combined with the wealth of the archaeological record in Beds I and II (with abundant, well-preserved, high-density, stratified assemblages), and the radiometric control over the age of the sites (which placed the earliest handaxes in Middle Bed II at around 1.4 ma), made Olduvai Gorge the world's reference for the emergence of the Acheulean in the following decades (see review by de la Torre and Mora, 2014). 
Although the relevance of Leakey's (1971) monograph can never be stressed enough, most subsequent discussions of the Oldowan-Acheulean transition did not involve first-hand reanalysis of the Olduvai collections, and some that did include a study of the original materials (e.g., de la Torre and Mora, 2005) highlighted problems that were unsolvable without renewed archaeological excavations at Olduvai. In this context, the Olduvai Geochronology Archaeology Project (OGAP) commenced fieldwork at Olduvai in 2008, and over the past decade has focused most of its efforts on gaining a better understanding of the geology, chronology, paleoecology and archaeology of Olduvai Bed II. During this phase of the project, OGAP's overarching aims (see details in de la Torre et al., 2012) have included an investigation of the ecological adaptations of late Oldowan and early Acheulean hominins, their technological skills and subsistence strategies, and a refinement of the chronostratigraphic framework in which such patterns unravelled.

As one of the major transitions in human evolution, it is an exciting time for those interested in the origins of the Acheulean and the evolutionary and cognitive patterns associated with the emergence of this technology (de la Torre, 2016). Recent findings suggest that handaxes may have appeared elsewhere in East Africa at around 1.76 Ma (Lepre et al., 2011; Beyene et al., 2013), and thus the Olduvai Acheulean is not the earliest. Nevertheless, the quality and quantity of its archaeological record, and the existence of Oldowan sites that are stratigraphically succeeded by Acheulean assemblages, still guarantee a pivotal role for Olduvai in the discussion of the transition. Proof of this is the renewed fieldwork interest in the Middle and Upper Bed II archaeological sequence (e.g., Dominguez-Rodrigo et al., 2014, 2017) which, in addition to the data presented by OGAP in this special issue, should contribute to shape a modern view of the origins of the Acheulean at Olduvai Gorge.

\section{Materials and methods}

This special issue compiles results of fieldwork by OGAP between 2008 and 2016, in which we conducted at least one field season annually and, in some years (2014 and 2015), two field seasons. Most of these eleven fieldwork seasons focused on a specific stratigraphic interval of the Olduvai Pleistocene sequence, that which captures the local transition from the Oldowan to the Acheulean between Lower and Upper Bed II, and involved the excavation of 57 trenches. OGAP's field strategy has combined the excavation of large trenches in some sites with high density of material -following Leakey's (1971) approach-with the landscape perspective inaugurated at Olduvai in 1989 by the Olduvai Landscape Paleoanthropology Project (OLAPP) (Blumenschine and Masao, 1991), and based on the excavation of randomly-placed trenches that sample targeted stratigraphic intervals. However, while Bed I and Lowermost Bed II contain stratigraphic layers that can be laterally followed across large extensions of Olduvai Gorge (Hay, 1976), the overlying stratigraphic units are more locally restricted, therefore limiting the paleogeographic range available for OGAP's random trenching, which is often limited to sampling within each of the outcrop localities defined by the Leakeys. Excavations between 2009-2016 focused on the eastern shoreline of the Olduvai paleolake, particularly at archaeological localities EF-HR, HWK EE, HWK E, FLK, FC (East and West) and MNK (Figure 1A), and sampled the top of Lower Bed II, throughout Middle Bed II, and the lower part of Upper Bed II (Figure 1B).

Apart from an overview of OGAP's research aims (de la Torre et al., 2012), digital mapping initiatives of the Gorge (Jorayev et al., 2016) and geochemical correlations (McHenry et al., 2016), this special issue is the first publication that presents a systematic account of OGAP's investigations. With the exception of two papers based on assemblages excavated by Mary Leakey (Proffitt, 2018; Pante and de la Torre, 2018), all articles in this volume use OGAP's materials as the main data source. Papers on the stratigraphy and geochronology of Bed II (McHenry and Stanistreet, 2018; Stanistreet et al., 2018) compile data obtained from all trenches excavated, plus additional information from natural outcrop 
logging and surveys. Papers on the paleoecological reconstruction of Bed II (Prassack et al., 2018; Bibi et al., 2018; Uno et al., 2018) also use entirely OGAP's materials (i.e., all fossils from 57 trenches through Bed II) as the main dataset, which in this case deserves special mention as they are almost exclusively assemblages derived from excavation, rather than surface collection. One of the papers on the archaeological record (McHenry and de la Torre, 2018) also includes materials from several of the localities sampled by OGAP, but the rest (de la Torre and Mora, 2018a, b; de la Torre et al., 2018a, b; Pante et al., 2018; Rivals et al., 2018; Arroyo and de la Torre, 2018) focus on two of the archaeological sites excavated by OGAP, namely HWK EE and EF-HR.

The rationale behind this variable selection of materials lies on the scale of analysis for each of the research questions discussed in this special issue. The geochronological and stratigraphic studies seek to clarify site correlations and present sedimentary and erosive dynamics through the sequence, and the papers on paleoecology investigate stability versus change of the paleoenvironmental context in which the Oldowan-Acheulean transition took place. Diachronic patterns are consubstantial to these lines of enquiry and therefore the entire OGAP Bed II dataset up to 2016 was considered.

Concerning the archaeological study, OGAP's current strategy is to report on full assemblages, rather than presenting preliminary accounts of unfinished excavations or a partial analysis of selected elements of some particular archaeological collections. This perspective precludes presenting here the archaeological results for the entire OGAP dataset, and we chose instead to focus on two key Olduvai paleoanthropological localities and their surroundings. The HWK EE site is stratigraphically located in the transition between Lower and Middle Bed II, and is one of the latest Oldowan sites at Olduvai, at $\sim 1.7$ ma. EF-HR sits in Upper Bed II at $1.4 \mathrm{ma}$, and the abundance of handaxes at the site points at an unequivocally Acheulean character for the assemblage. These two sites were selected for large-scale excavations and publication in this special issue because they are in the stratigraphic endpoints of the interval under study and, in addition, they are some of the most productive assemblages in the entire Olduvai sequence. This provides the unique opportunity to develop a comparative framework to interpret changes in faunas, paleoenvironments, and stone tools, and to contextualise such framework within a detailed chronostratigraphic background provided by the tephrostratigraphic and high-resolution sedimentary studies presented in this volume.

The 16 papers that follow cover a wide range of disciplines and expertise, including tephrostratigraphy, sedimentology, micromorphology, diatoms, stable isotopes, phytoliths, vertebrate systematics, tooth wear, archaeological conservation, taphonomy, zooarchaeology, stone tool technology, lithic use wear, spatial analysis and geostatistics. They involve 29 different contributors from research centres in 11 countries. While all papers aim to present discussions relevant to broad paleoanthropological questions, there is also a deliberate emphasis on the production of data-rich articles, where pictures, illustrations, diagrams and supplementary online material (interactive models of excavations in HWK EE and EF-HR, and 3D reconstructions of outcrops, archaeological units and artefacts) play an essential role.

In summary, the substantial sample excavated across one very specific stratigraphic interval, the wide range of expertise dedicated to investigate one particular research problem, and the importance given to the presentation of raw data from entire assemblages, construct a piece of reference for the study of the Oldowan-Acheulean transition at Olduvai, and produce an empirical corpus and a methodological framework that can now be used by other researchers.

\section{Results}

The chrono-stratigraphic framework 
Bed II records a more complicated depositional and erosive history than Bed I (Hay, 1976), and the use of tuffs as stratigraphic markers is hindered by lateral discontinuities and the reworking and alteration of volcanic glass, which also makes dating of Bed II less precise than that of Bed I (Deino, 2012). McHenry and Stanistreet (2018) recalibrate previous radiometric dates for Bed II, and use mineralogical and geochemical fingerprints of tuffs to constrain the Bed II stratigraphy.

Their results are particularly relevant to pin down the appearance of first handaxes at Olduvai, as they position new Acheulean findings at FLK West (Diez-Martin et al., 2015) in Middle Bed II rather than in Lower Bed II (Uribelarrea et al., 2017). McHenry and Stanistreet (2018) also report that EF-HR sits above the level of Tuff IIC instead of below (Hay, 1976), which therefore locates the site in Upper Bed II, rather than in Middle Bed II (Leakey, 1971). A revised stratigraphic framework for Bed II is presented by Stanistreet et al. (2018), who use a sequence stratigraphy approach to distinguish five major sequences bounded by deeply incised discontinuities. This perspective justifies the redefinition of the Lower to Middle Bed II boundary above the Lemuta Member (McHenry et al., 2016) instead of in Tuff IIA (Leakey, 1971), enables the identification of lake para-sequences throughout Bed II, and describes the significant erosive processes that have led to previous misplacements of early Acheulean occurrences (Stanistreet et al., 2018).

\section{Paleoecology of Bed II}

Whether or not the technological transition between the Oldowan and the Acheulean can be associated with paleoecological changes across the Olduvai basin is one of the key questions investigated in this special issue. Papers on bird (Prassack et al., 2018), fish and large mammal (Bibi et al., 2018) communities, and on isotope and wear of mammal teeth (Uno et al., 2018), use the same scale of analysis (i.e., three fossil assemblages that include all materials from the 57 excavated trenches separated by stratigraphic intervals: see Figure 1B) to address this question, so that results from each proxy can be consistently compared.

Variation in bird communities from Oldowan (Assemblage IIA) to Acheulean (Assemblages IIB and IIC) units suggests an increasing expansion of grasslands and open woodlands, and a more open and drier environment than in Lowermost Bed II (Prassack et al., 2018). Fish and large mammal communities (Bibi et al., 2018) support that open and seasonal grassland habitats dominated in the three assemblages, but do not record any major turnover across the sequence; the Olduvai paleoenvironmental settings remained open and dry throughout Bed II (Bibi et al., 2018). Assemblage IIB sees a decrease in the number of $C_{3}$ and mixed feeders, and an increase on the abrasiveness of the diet (Uno et al., 2018). Nonetheless, both stable isotopes and tooth wear analyses report no major changes in hydrology and vegetation across the sequence (Uno et al., 2018), and thus support results by Bibi et al. (2018) on the structural continuity of large mammal communities.

\section{Archaeological contexts}

The Oldowan site of HWK EE was discovered and originally excavated by Mary Leakey, but she never published her work at this locality. Pante and de la Torre (2018) analyse the rich fossil and stone tool assemblage excavated by Leakey, and contextualise it within recent fieldwork at HWK EE. New excavations at the site are detailed by de la Torre et al. (2018a), who describe the stratigraphic and paleoecological settings of $\mathrm{HWK} \mathrm{EE}$, and discuss formation processes of the assemblage. With a large fossil and lithic assemblage straddling the Lower to Middle Bed II boundary, HWK EE was deposited in a river and marshy wetland freshwater environment, with both grass and trees nearby. The fossil and lithic deposit contains a multi-layered stack of archaeological units that show variable degrees of 
human activity and disturbance by water, which contributed to the formation of the assemblage alongside other agents such as hominins, crocodiles and mammal carnivores (de la Torre et al., 2018a).

Fieldwork in the EF-HR complex (de la Torre et al., 2018b) included excavations in twelve trenches that covered around $1 \mathrm{~km}^{2}$ across which the same handaxe-bearing stratigraphic unit can be traced. Early Acheulean activity is pervasive within the sampled area, but conspicuous differences in the density of archaeological materials are observed across the paleolandscape. Stone artefacts are highly clustered around the main EF-HR trench, which was situated in the deepest part of an incised valley and which contained a stable water source with trees probably adjacent to it, in a generally open environment with grasses (de la Torre et al., 2018b). Possible scenarios explaining the large stone tool accumulation around the main trench are explored by de la Torre and Wehr (2018), who discuss the role of postdepositional processes and conclude that fluvial erosion and re-deposition played a significant part in shaping the configuration of the archaeological assemblage.

\section{Carnivore- hominin interactions}

HWK EE may represent one of the last appearances of Homo habilis at Olduvai, and the large fossil assemblage recovered from the site enables discussions on seasonality (Rivals et al., 2018) and the feeding behaviour of hominins and carnivores (Pante and de la Torre, 2018; Pante et al., 2018). Tooth wear and stable isotope data indicate that, while there are no significant changes in bulk diet or hydroclimate between the lower (Lemuta) and upper (Lower Augitic Sandstone [LAS]) deposits, differences exist in the vegetation consumed by HWK EE ungulates (Rivals et al., 2018). These authors thus suggest that the LAS deposits were accumulated mostly during relatively dry periods, in which grasses were less readily available than in Lemuta, and grazing animals may have been more stressed nutritionally.

Hominins are inferred to have broken most of the limb bones at HWK EE, although both hominins and carnivores had some access to flesh (Pante and de la Torre, 2018). Hominins obtained substantial amounts of flesh and marrow from smaller mammals, but they scavenged much of their animal foods from carnivores (Pante et al., 2018). The contribution of both hominins and carnivores to the formation of the bone assemblage at EF-HR is also attested (de la Torre et al., 2018b), although in this case the fragmentary condition of fossils does not allow for discussions on the character of such interaction.

\section{Technological strategies}

Potential diachronic patterns within the Oldowan at Olduvai Gorge are discussed by Proffitt (2018), who studied lithic assemblages excavated by Leakey (1971) from Bed I and the lower part of Bed II. According to Proffitt (2018), technological differences between the classic Oldowan and the Developed Oldowan A are not significant enough to warrant the separation proposed by Leakey (1971) between the two facies, and he attributes the perceived differences to raw material availability and use. De la Torre and Mora (2018a) study the large lithic assemblage unearthed by OGAP at HWK EE, and are less confident than Proffitt (2018) about the absence of marked techno-typological differences between the classic and the late Oldowan, although the expediency and low skill shown in corereduction methods shared in both periods is also emphasized (de la Torre and Mora, 2018a; Pante and de la Torre, 2018).

While Proffitt (2018), de la Torre and Mora (2018a) and Pante and de la Torre (2018) deal with assemblages placed stratigraphically before the first Large Cutting Tools (LCTs) are found in the Olduvai sequence (McHenry and Stanistreet, 2018; Stanistreet et al., 2018), the technological analysis of EF-HR (de la Torre and Mora, 2018b) presents a snapshot of what an uncontested early Acheulean 
assemblage was like after Tuff IIC, i.e., once LCTs had appeared at Olduvai in post-Tuff IIB contexts. De la Torre and Mora (2018b) highlight the shortness and discontinuity of shaping processes and the lack of planform and biconvex symmetry in the LCT production. However, they also emphasize the existence of standardized procedural patterns, fixed technical rules and particular mental templates that indicate a structured technological behaviour during the early Acheulean.

Apart from the obvious differences in tool-types and flaking/ shaping techniques between Oldowan (HWK EE) and Acheulean (EF-HR) assemblages (de la Torre and Mora, 2018a, b), further comparisons can be made in other technological categories such as percussive artefacts (Arroyo and de la Torre, 2018), and in raw material procurement (McHenry and de la Torre, 2018). Arroyo and de la Torre (2018) describe techno-typological macroscopic features and microscopic use-wear of pounding tools at EF-HR and HWK EE, and conclude that the Oldowan battered assemblage reflects a wider range of tasks than in the Acheulean site. McHenry and de la Torre (2018) discuss raw material sourcing and use collections from several of the localities sampled by OGAP to propose a classification protocol of Olduvai Bed II rock types, which is then applied to the entire assemblages of HWK EE and EF-HR. They conclude that late Oldowan hominins from HWK EE selected preferentially raw materials according to blank shape and suitability of natural angles for flaking, rather than based on rock texture. In contrast, early Acheulean hominins at EF-HR showed no clear selectivity in blanks for small core debitage, but preferred high-quality raw materials for LCT production.

\section{From the Oldowan to the Acheulean at Olduvai Gorge}

The breadth of papers in this special issue attempts to attain an updated, comprehensive view of geochronological, paleoenvironmental and behavioural patterns associated with the transition from the Oldowan into the Acheulean at Olduvai. According to the results presented in this special issue, the earliest Acheulean appeared at Olduvai after Tuff IIB in Middle Bed II, at around 1.66 ma, and core-and-flake assemblages devoid of handaxes are confined to the pre-Tuff IIB sequence (McHenry and Stanistreet, 2018; Stanistreet et al., 2018). Similarity of core reduction methods across Bed I and pre-Tuff IIB assemblages indicate continuity of flaking techniques in classic and late Oldowan sites, although raw material (Proffitt, 2018) and tool-type differences (de la Torre and Mora, 2018) are observed between the pre-Lemuta (i.e. Bed I and Lowermost Bed II) and those assemblages originally termed Developed Oldowan A by Leakey (1971).

While the composition of bird assemblages seems to change after Lowermost Bed II (Prassack et al., 2018), substantial changes in large mammal communities are only detected between Middle Bed I and the sequence above (Bibi et al., 2018). Hydrology and vegetation remained similar between the top of lower Bed II and Upper Bed II (Uno et al., 2018), and large-mammal communities underwent no substantial changes during this period (Bibi et al., 2018), although seasonal paleoecological variations are detected locally (Rivals et al., 2018). Therefore, neither variations observed between classic and late Oldowan assemblages, nor the major technological change from the Oldowan to the Acheulean, can be readily associated with major faunal turnovers at Olduvai. Environments were open across the area sampled by OGAP in the eastern side of the Olduvai paleolake (Bibi et al., 2018; Prassack et al., 2018; Uno et al., 2018), with archaeological sites such as HWK EE (de la Torre et al., 2018a) and EF-HR (de la Torre et al., 2018b) near watercourses with some tree cover.

HWK EE hominins acquired meat and marrow mainly through scavenging (Pante and de la Torre, 2018; Pante et al., 2018) and sourced raw materials locally (McHenry and de la Torre, 2018), which they used in flaking (de la Torre and Mora, 2018a) and pounding (Arroyo and de la Torre, 2018) activities. At 1.7 
ma, HWK EE is one of the latest Oldowan sites at Olduvai, but the distinctiveness of its technology with respect to previous Oldowan assemblages (de la Torre and Mora, 2018a) does not herald the technological change brought about with the Acheulean. Approximately 300,000 years apart, EF-HR suggests that by $\sim 1.4 \mathrm{Ma}$ LCT production was a usual technical behaviour which followed wellestablished procedural patterns (de la Torre and Mora, 2018b), using high-quality raw materials (McHenry and de la Torre, 2018) that led to substantial concentrations of stone tools in particular areas of the landscape (de la Torre et al., 2018b; de la Torre and Wehr, 2018).

HWK EE and EF-HR represent the endpoints of the stratigraphic interval that capture the OldowanAcheulean transition at Olduvai, and potentially also the emergence of Homo erectus and the disappearance of Homo habilis (Leakey, 1975). By describing these sites in detail here, and presenting the geochronological and paleoecological setting of this transition, we aim to establish the features that define each technocomplex, and their paleonvironmental background. OGAP has also conducted substantial excavations in the stratigraphic interval between those two endpoints, and archaeological results of such fieldwork will be presented in future years.

\section{Acknowledgements}

Our thanks to the contributors to this special issue for their hard work and commitment to make it happen. We are also thankful to Mark Teaford and the many external reviewers of the papers in this special issue for their feedback. Special mention deserves Sarah Elton, whose dedication went far beyond what we expected from a journal editor. Our deep appreciation goes to Rob Blumenschine and Fidelis Masao (co-directors of OLAPP) for their support during the early stages of the project. We also thank Felista Mangalu (Natural History Museum of Arusha) and John Paresso (Olduvai Gorge station) for their logistical assistance. We are grateful for their contribution during excavation, laboratory and conservation work to all Tanzanian assistants and Tanzanian and foreign students and graduates, particularly to Norah Moloney (manuscript editing), Carmen Martin Ramos (finds processing), Goodluck Peter, Agustino Venance, Abel Lukas, Adrian Arroyo and Tomos Proffitt (trench supervision), Lekipa Lekaya (fieldwork assistance), Daniel Mainoya (conservation), and to the late John Msafiri, Richard Bakari and Jesuit Temba. OGAP fieldwork was authorised by the Tanzanian Commission for Science and Technology (COSTECH), the Ngorongoro Conservation Area Authority, and the Department of Antiquities. Major funding from the National Science Foundation (BCS0852292) and the European Research Council (Starting Grants-283366) is gratefully acknowledged. Further acknowledgements are given at the end of each contribution to this special issue.

\section{References}

Arroyo, A., de la Torre, I., 2018. Pounding tools in HWK EE and EF-HR (Olduvai Gorge, Tanzania). Percussive activities in the Oldowan-Acheulean transition. J. Hum. Evol.

Beyene, Y., Katoh, S., WoldeGabriel, G., Hart, W.K., Uto, K., Sudo, M., Kondo, M., Hyodo, M., Renne, P.R., Suwa, G., Asfaw, B., 2013. The characteristics and chronology of the earliest Acheulean at Konso, Ethiopia. PNAS 110, 1584-1591.

Bibi, F., Pante, M., Souron, A., Stewart, K., Varela, S., Werdelin, L., Boisserie, J.-R., Fortelius, M., Hlusko, L., Njau, J., de la Torre, I., 2018. Paleoecology of the Serengeti during the Oldowan-Acheulean transition at Olduvai Gorge, Tanzania: The mammal and fish evidence. J. Hum. Evol. 
Blumenschine, R.J., Masao, F.T., 1991. Living sites at Olduvai Gorge, Tanzania? Preliminary landscape archaeology results in the basal Bed II lake margin zone. J. Hum. Evol. 21, 451-462.

Curtis, G.H., Hay, R.L., 1972. Further geological studies and potassium-argon dating at Olduvai Gorge and Ngorongoro Crater. In: Bishop, W.W. and Miller, J.A. (eds) Calibration of Hominoid Evolution Recent advances in isotopic and other dating methods as applicable to the origin of man. Scottish Academic Press, Edinburgh, pp 289-301.

de la Torre, I., 2016. The origins of the Acheulean: past and present perspectives on a major transition in human evolution. Phil. Trans. R. Soc. Lon. B 371, 20150245.

de la Torre, I., Albert, R.M., Arroyo, A., Macphail, R., McHenry, L.J., Mora, R., Njau, J.K., Pante, M.C., Rivera-Rondón, C.A., Rodríguez-Cintas, Á., Stanistreet, I.G., Stollhofen, H., Wehr, K., 2018. New excavations at the HWK EE site: Archaeology, paleoenvironment and site formation processes during late Oldowan times at Olduvai Gorge, Tanzania. J. Hum. Evol.

de la Torre, I., Albert, R.M., Macphail, R., McHenry, L.J., Pante, M.C., Rodríguez-Cintas, Á., Stanistreet, I.G., Stollhofen, H., 2018. The contexts and early Acheulean archaeology of the EF-HR paleo-landscape (Olduvai Gorge, Tanzania). J. Hum. Evol.

de la Torre, I., McHenry, L.J., Njau, J.K., Pante, M.C., 2012. The Origins of the Acheulean at Olduvai Gorge (Tanzania): A New Paleoanthropological Project in East Africa. Archaeology International 15, 89-98.

de la Torre, I., Mora, R., 2005. Technological Strategies in the Lower Pleistocene at Olduvai Beds I \& II. ERAUL 112, Liege.

de la Torre, I., Mora, R., 2014. The Transition to the Acheulean in East Africa: an Assessment of Paradigms and Evidence from Olduvai Gorge (Tanzania). J. Arch. Met. Theo. 21, 781-823.

de la Torre, I., Mora, R., 2018. Oldowan technological behaviour at Olduvai Gorge, Tanzania: The HWK EE stone tool assemblage. J. Hum. Evol.

de la Torre, I., Mora, R. 2018. Technological behaviour in the early Acheulean of EF-HR (Olduvai Gorge, Tanzania). J. Hum. Evol.

de la Torre, I., Wehr, K., 2018. Site formation processes of the early Acheulean assemblage at EF-HR (Olduvai Gorge, Tanzania). J. Hum. Evol.

Deino, A.L., 2012. 40Ar/39Ar dating of Bed I, Olduvai Gorge, Tanzania, and the chronology of early Pleistocene climate change. J. Hum. Evol. 63, 251-273.

Diez-Martín, F., Sánchez Yustos, P., Uribelarrea, D., Baquedano, E., Mark, D.F., Mabulla, A., Fraile, C., Duque, J., Díaz, I., Pérez-González, A., Yravedra, J., Egeland, C.P., Organista, E., Domínguez-Rodrigo, M., 2015. The Origin of The Acheulean: The 1.7 Million-Year-Old Site of FLK West, Olduvai Gorge (Tanzania). Scientific Reports 5, 17839.

Domínguez-Rodrigo, M., Pickering, T.R., Baquedano, E., Mabulla, A., Mark, D.F., et al., 2013. First partial skeleton of a 1.34-million-year-old Paranthropus boisei from Bed II, Olduvai Gorge, Tanzania. PLOS ONE 8 (e80347).

Domínguez-Rodrigo, M., Diez-Martín, F., Mabulla, A., Baquedano, E., Bunn, H.T., Musiba, C., 2014. The evolution of hominin behavior during the Oldowan-Acheulean transition: Recent Evidence from Olduvai Gorge and Peninj (Tanzania). Quat. Int., 322-323: 1-314. 
Domínguez-Rodrigo, M., Baquedano, E., Mabulla, A., Diez-Martín, F., Egeland, C.P., 2017. Oldowan and Acheulian archaeology of Olduvai Gorge. Boreas, 46: 605-936.

Hay, R.L., 1976. Geology of the Olduvai Gorge. University of California Press, Berkeley.

Jorayev, G., Wehr, K., Benito-Calvo, A., Njau, J., de la Torre, 2016. Imaging and photogrammetry models of Olduvai Gorge (Tanzania) by Unmanned Aerial Vehicles: A high-resolution digital database for research and conservation of Early Stone Age sites. J. Archaeol. Sci. 75, 40-56.

Leakey, L.S.B., 1936. Stone Age Africa. An outline of Prehistory in Africa. Oxford University Press, London.

Leakey, L.S.B., 1951. Olduvai Gorge. A Report On The Evolution Of The Hand-Axe Culture In Beds I-IV. Cambridge University Press, Cambridge.

Leakey, L.S.B., Hopwood, A.T., Reck, H., 1931. New Yields from the Oldoway Bone Beds, Tanganyika Territory. Nature 128, 1075.

Leakey, M.D., 1971. Olduvai Gorge. Vol 3. Excavations in Beds I and II, 1960-1963. Cambridge University Press, Cambridge.

Leakey, M.D., 1975. Cultural Patterns in the Olduvai Sequence, in: Butzer, K.W., Isaac, G.L. (Eds.), After the Australopithecines. Stratigraphy, Ecology, and Cultural Change in the Middle Pleistocene. Mouton, Chicago, pp. 477-493.

Lepre, C.J., Roche, H., Kent, D.V., Harmand, S., Quinn, R.L., Brugal, J.-P., Texier, P.-J., Lenoble, A., Feibel, C.S., 2011. An earlier origin for the Acheulian. Nature 477, 82-85.

Manega, P.C., 1993. Geochronology, geochemistry and isotopic study of the Plio-Pleistocene Hominid sites and the Ngorongoro volcanic highland in Northern Tanzania. Ph.D. Dissertation, University of Colorado, Boulder, $382 \mathrm{p}$.

McHenry, L.J., Njau, J.K., de la Torre, I., Pante, M.C., 2016. Geochemical "fingerprints" for Olduvai Gorge Bed II tuffs and implications for the Oldowan-Acheulean transition. Quat. Res. 85, 147-158.

McHenry, L., de la Torre, I., 2018. Hominin raw material procurement in the Oldowan-Acheulean transition at Olduvai Gorge. J. Hum. Evol.

McHenry, L., Stanistreet, I., 2018. Tephrochronology of Bed II, Olduvai Gorge, Tanzania, and the chronology of the Oldowan-Acheulean transition. J. Hum. Evol.

Pante, M.C., de la Torre, I., 2018. A hidden treasure of the Lower Pleistocene at Olduvai Gorge, Tanzania: The Leakey HWK EE assemblage. J. Hum. Evol.

Pante, M.C., Njau, J.K., Hensley-Marschand, B., Keevil, T.L., Martín-Ramos, C., Peters, R.F., de la Torre, I., 2018. The carnivorous feeding behavior of early Homo at HWK EE, Bed II, Olduvai Gorge, Tanzania. J. Hum. Evol.

Prassack, K., Pante, M.C., Njau, J.K., de la Torre, I., 2018. The Paleoecology of Fossil Birds from Middle Bed II, at Olduvai Gorge, Tanzania J. Hum. Evol.

Proffitt, T. 2018. Diachronic changes in Oldowan technology in Beds I and Lower Bed II. J. Hum. Evol.

Rivals, F., Uno, K.T., Bibi, F., Pante, M.C., Njau, J., de la Torre, I., 2018. Dietary traits of the ungulates from the HWK EE site at Olduvai Gorge (Tanzania): Diachronic changes and seasonality. J. Hum. Evol. 
Stanistreet, I., Stollhofen, H., McHenry, L.J., de la Torre, I., 2018. Bed II Sequence Stratigraphic context of EF-HR and HWK EE archaeological sites, and the Oldowan/ Acheulean succession at Olduvai Gorge, Tanzania. J. Hum. Evol

Uno, K.T., Rivals, F., Bibi, F., Pante, M., Njau, J.K., de la Torre, I., 2018. Large mammal diets and paleoecology across the Oldowan-Acheulean transition at Olduvai Gorge, Tanzania from stable isotope and tooth wear analyses. J. Hum. Evol.

Uribelarrea, D., Martín-Perea, D., Díez-Martín, F., Sánchez-Yustos, P., Domínguez-Rodrigo, M., Baquedano, E., Mabulla, A., 2017. A reconstruction of the paleolandscape during the earliest Acheulian of FLK West: The co-existence of Oldowan and Acheulian industries during lowermost Bed II (Olduvai Gorge, Tanzania). Palaeogeogr. Palaeoclimatol. Palaeoecol. 488, 50-58.

\section{Legends}




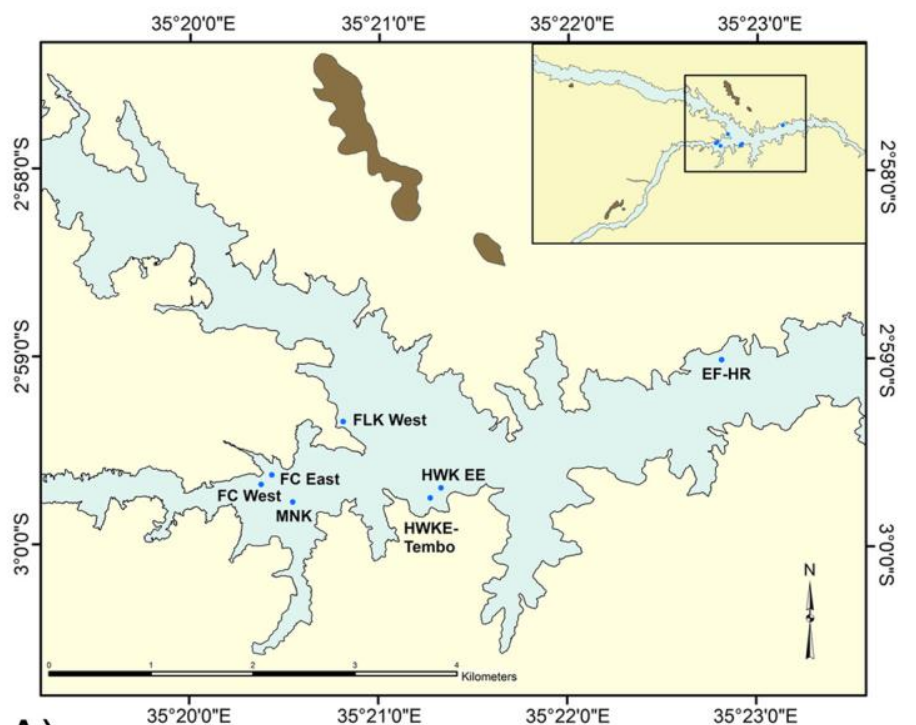

A)
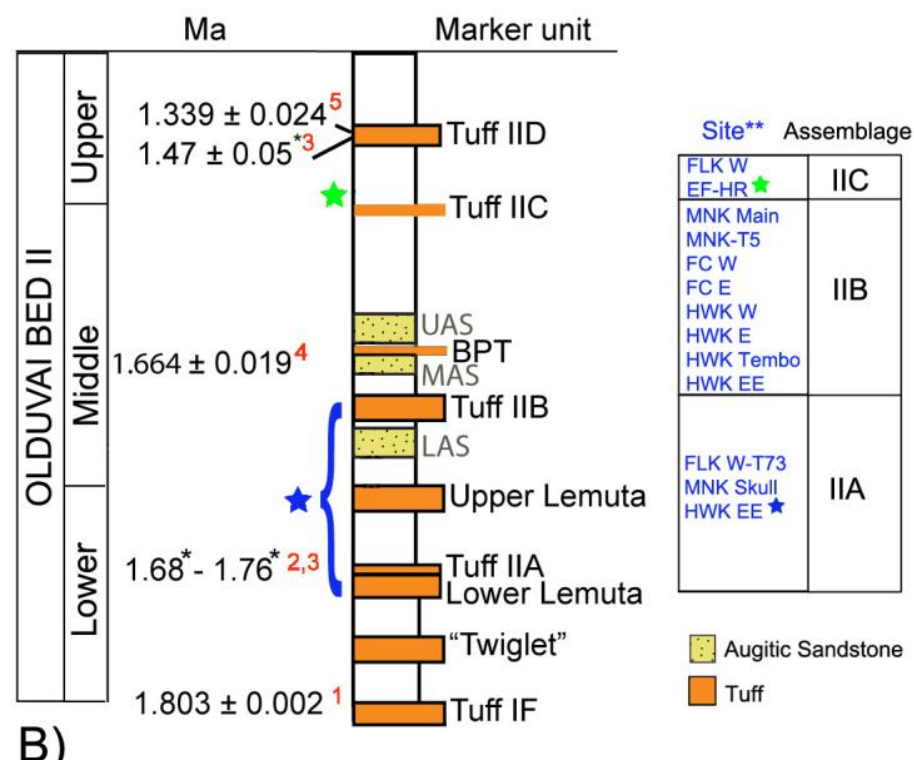

B)

Figure 1. A) Map with localities excavated by OGAP at Olduvai Gorge (base map after Jorayev et al., 2016). B) Simplified stratigraphy of Bed II (composite section), with the stratigraphic position of localities investigated by OGAP. * Dates from: (1) Deino, 2012; (2) Curtis and Hay, 1972, updated in McHenry and Stanistreet, 2018; (3) Manega, 1993, updated in McHenry and Stanistreet, 2018; (4) Diez-Martín et al., 2015; (5) Domínguez-Rodrigo et al., 2013. ** Archaeological sites within each assemblage are not plotted in stratigraphic order. 